
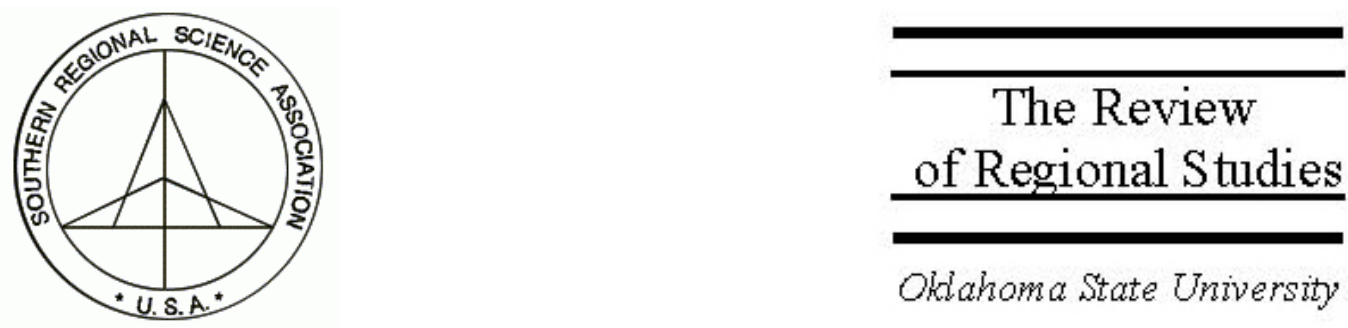

\title{
Effectiveness of Credit Pooling in Financing Infrastructure for Economic Growth in Southern Rural Counties - A Quasi-Experimental Approach
}

\author{
Mona Ray \\ Department of Economics, Morehouse College, 830 Westview Dr. SW \\ Atlanta, GA 30314, e-mail: mray@morehouse.edu \\ James C. Hite \\ Department of Agricultural and Applied Economics, Clemson University, Clemson, \\ South Carolina,e-mail: dochite@aol.com
}

\begin{abstract}
In this research, the method of quasi-experimentation is used to study the effects of adopting the credit pooling technique in financing infrastructure development in rural areas, thereby enhancing economic development. A difference in economic growth between the treated and control counties, if any, in the post treatment period is attributed to the treatment effect. Findings indicate some positive impact by raising the per capita income and income growth in some important sectors of the economy. However, that could be due to other treatments during the same period, which could not be controlled for in this study.
\end{abstract}

Keywords: Quasi-experimental method; Credit pooling; Infrastructure development; Economic growth

JEL classification: H27; O18; R51

This research was done towards the fulfillment of the Ph.D. dissertation of the senior author and funded by the Tennessee Valley Authority (TVA) 


\section{INTRODUCTION}

Public works projects establish the physical network upon which the country's economy depends - its infrastructure. Although most easily thought of in a physical form - a bridge, a wastewater treatment plant, or an airport terminal - the real output of infrastructure is service: the movement of people and goods and the provision of adequate clean water. Infrastructure is a vital tool of economic growth and public health.

Investments in such infrastructure are often speculative since in any given place there may or may not be subsequent development that generates a cash flow sufficient to service debt incurred in putting the infrastructure in place. Because the risk of defaulting on debt payment is high (or difficult to assess), the cost of funding infrastructure in rural communities often is prohibitive. Credit pooling has evolved as one way to spread risks. The question to be answered by this research is whether there is any statistically credible evidence that such pooling results in faster rates of economic growth in rural counties.

The method of quasi-experiment is adopted to search for this answer. This study is a novel approach to identifying the impact of this relatively new technique of financing infrastructure investment on the economy of the local area. It is significant because its empirical insights may provide some hints to the policy makers of the rural areas when making a choice in the technique to finance infrastructure investment.

The paper begins with a general background discussion of the relationship between infrastructure and economic growth and the special problems of financing infrastructure in small rural places, which credit pools are designed to address. Then follow sections on the quasi-experimental methodology and its application in this particular study and the results of empirical analysis. The final section provides summaries and conclusions.

\section{BACKGROUND: INFRASTRUCTURE FINANCE AND RURAL GROWTH}

Federally subsidized funding for rural infrastructure development was the favored policy approach until a few years ago. But ever-tightening federal budgets have undermined that policy approach (U.S. General Accounting Office 2001). The market for municipal securities was greatly affected by the enactment of the Tax Reform Act of 1986. The new tax provisions influenced both the demand for and the supply of taxexempt securities. To avoid the high costs of selling in the national bond market, rural communities tend to borrow from local sources, typically local banks (U.S. Dept of Agriculture 1990).

The reduced intergovernmental aid and volatile bond markets have caused states and local communities to experiment with all sorts of alternatives to standard bond issues: zero-coupon bonds, compound interest bonds, stripped or stepped coupon bonds, tender option bonds, super sinker bonds, floating or flexible rate bonds, and other rarified forms. Most of these new techniques shift the financial burden away from the taxpaying base at large and toward the individuals and firms who benefit directly from the new or improved 
infrastructure. That is, most of these approaches rely on user-based financing (National League of Cities 1987).

\subsection{Credit Pooling Techniques}

The three most prevalent financing mechanisms followed by local bodies are bond banks, revolving loan funds, and substate credit pools - all of which can be broadly categorized as credit pooling techniques. Credit pooling techniques are designed to raise infrastructure capital and have become increasingly sophisticated, inventive, and aggressive. They combine the underlying borrowers and their credit resources to enjoy economies of scale, thereby lowering the costs of borrowing for financing individual capital projects. The technique spreads risks across communities; by consolidating loans into pools, larger issues result and thus wider distribution and lower issuance costs (printing, disclosure, ratings, etc.), enabling small communities to enjoy some economies of scale in accessing capital markets.

The state credit pools buy the bonds issued by specific communities for water and wastewater facilities, bundle those bonds together in a single package, and use them as collateral for bonds that the credit pools sell in the money market (Petersen et al. 1988). Investors who purchase bonds issued by the state credit pools assume risks associated with the repayment abilities of all of the communities whose bonds are bundled together. Hence, investors are not exposed directly to the risk of non-growth in a specific rural place, but to the more general risk of non-growth in the rural places of a specific state.

In the bond bank, a state-sponsored intermediary borrows money, which it in turn relends to participating local governments. Substate pools are closely related in concept to state bond banks in the sense that the pool aggregates several local bond issues into a single bond issue, which it sells in the national market. However, the pooling authority is merely a financing conduit; the resources of the participants alone are used to repay the debt. The loss of arbitrage earnings because of the Tax Reform Act of 1986 has made the substate pools less popular since the late 1980s. Similarly, the bond banks have been successful only in areas that had strong state credit, i.e., high bond rating and a profusion of smaller, lower-rated or non-rated local borrowers (Illyes 1985).

State Revolving Loan Funds (SRF) differ from bond banks in that the initial capitalization for such funds comes from state appropriations rather than from the sale of bonds. The principal of the fund, once established, is not used to retire principal but is revolved or rolled over to make additional loans. Because of the permanent portion of the fund of the SRF that is not lent out, this reserve increases the security behind any borrowings done externally. Consequently, over the years, state revolving funds have grown in popularity.

Accordingly, this research attempts to study the impact of the SRF as a method of pooling funds. Figure 1 illustrates the overall structure of a typical revolving fund. For both types of fund - leveraged and un-leveraged - the interest rates charged can be at 
market rate or lower if the state elects to subsidize the fund's loans. SRF programs provide one or more of the following financing services to their users: (1) provision of direct loans to municipalities, often at below-market interest rates, either as a lender of last resort for communities with poor ratings or for all communities at subsidized interest rates; (2) provision of credit enhancement for borrowings in the private market. Rather than providing funds from the SRF, some of the programs help municipalities raise funds in the private market through credit support programs such as bond insurance; (3) guarantee of municipal loans with the capitalization funds. This entails a pledging of the fund's assets to repaying debt.

\subsection{Studies Concerning Financing For Rural Infrastructure Development}

The existing body of literature hints at a possible causal linkage between the financing technique for infrastructure investment and the subsequent enhancement in economic development. Johnson (1996) estimated the differential impacts of alternative strategies involved in providing infrastructure. His hedonic land-pricing model reveals that issues like choice of alternative infrastructure investments, policy-based on economic analyses

SOURCE OF FUNDS

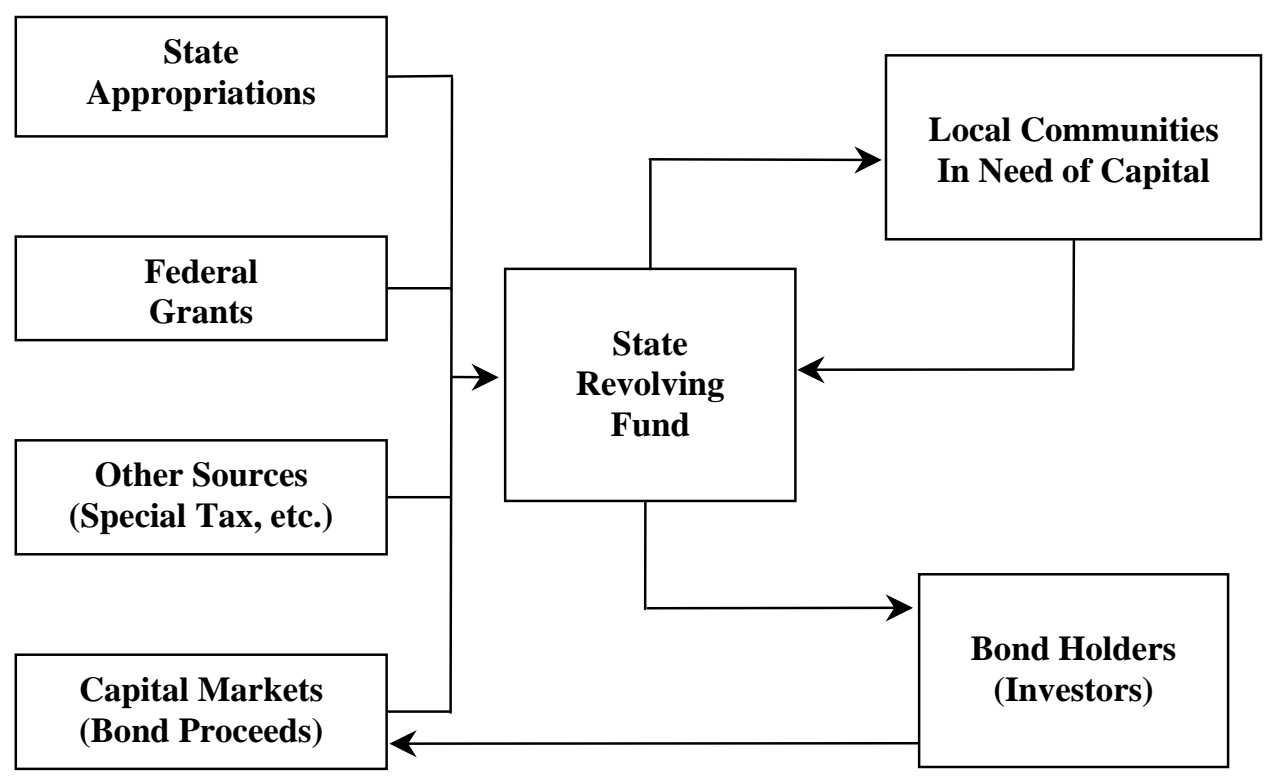

Sources: Smith, Barney, Harris, Upham \& Co. National Conference of State Legislatures, Financing Clean Water: A Shift in State Initiative (1987).

FIGURE 1. Financial Cycle of a State Revolving Fund 
of investment alternatives, alternative means of financing infrastructure, and rationalization of existing infrastructure play an important role in impacting the economic development.

Sears, Rowley, and Reid (1990), in their effort to study the linkage between infrastructure and economic development, found certain necessary and sufficient situations to play an important role in determining this linkage. In addition, they found certain other key variables to influence the nature and extent of the likely economic development effects of an infrastructure investment. These are metro versus non-metro location; intraregional location; existing state of infrastructure; industrial composition; characteristics of the community; and type of infrastructure investment, short-term versus long-term perspective.

Fox and Smith (1990) examined the linkage between infrastructure and economic development by classifying regions into three categories - intermediate, congested, and lagging - according to their current level of development and the presence of ingredients for further development. Their study showed that intermediate regions had the greatest potential for economic development through enhanced infrastructure investment.

Fox (1988) tried to answer the question "do infrastructure investments promote economic development?” by discussing three possible influencing factors: the linkage between economic development and infrastructure, the manner in which infrastructure is financed, and the existing economic development of the community. He described the causal link in three ways: through the supply side, the demand side, and the redistributive effects. Fox suggested that infrastructure needs should be evaluated through examination of individual communities. The analysis should be dynamic rather than static, based on consideration of structural changes in the economy and trends in the location of people and business.

Figure 2 shows how this research attempts to explain the causal relationship between the credit pooling technique for financing public infrastructure and the subsequent enhancement in economic development.

\section{QUASI-EXPERIMENTAL METHODOLOGY}

The term "quasi-experimental" refers to research designs that have most aspects of an experiment (Cook and Campbell 1979). They have a treatment, an outcome measure, and a control group whose experience serves as a baseline against which the effects of treatment can be measured. However, there is non-randomness in assignment to treatment and control group before treatment occurs. The control group is selected after the treatment has happened and in a manner that permits isolating the treatment effect.

There exists a vast body of literature in regional science utilizing a quasiexperimental method for empirical research. But none could be found using this method for studying an impact analysis similar to the present research. It has been used to study 


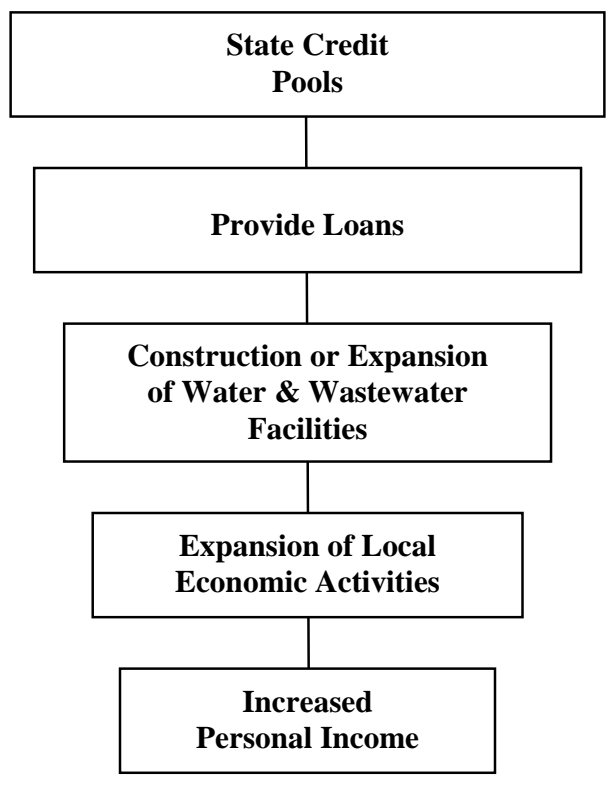

FIGURE 2. Credit Pooling Technique and Economic Development-A Causal Linkage

the impact of highway constructions (Blum 1982; Briggs 1980; Isserman 1987), airport services (Wheat 1970; Farnsworth 1972), fiscal policies (Bender and Schwiff 1982), and population projections (Isard 1960), to name a few.

\subsection{Design Concepts}

The quasi-experimental design used in this research may be thought of as a combination of the "non-equivalent untreated control group design" and the "interrupted timeseries design" identified by Campbell and Stanley (1963). The essence of the method is to match policy treated counties with untreated ones that have similar economic and spatial characteristics. The method of constructing the without-treatment baseline adopts the former design. This baseline is subsequently used to measure economic effects and to perform statistical tests. The practice of dividing the period of analysis into multiple periods adopts the latter design.

Three different time periods have been set up for this analysis. The first is the "selection period.” During this period, a calibration method is used to identify the control group. The second is the "selection test period," when a statistical test is conducted to evaluate the validity of the control group or, more specifically, of its ability to trace out accurately the growth path of the treated county or counties in the absence of the treatment. This period stretches from the end of the selection period to just before treatment begins. The third is the "treatment test period," which starts the year before treatment 
occurs. A treatment effect is identified if the actual and the counterfactual growth path diverge during this period and their difference is statistically significant.

Figure 3 shows a hypothetical, ideal case (Isserman 1994). There is no significant difference between the growth paths of the treated counties and the control counties during the selection period, in part because growth rates during that period are used to select the control group. Likewise, there is no difference in the selection test period. During the treatment test period, they begin to diverge. The difference between the treated path (actual) and the control group path (counterfactual) is the treatment effect.

\subsection{Selecting Treatment Groups}

In this study, particular attention is paid to the rural areas of the states of Alabama, Florida, Georgia, Kentucky, Mississippi, North Carolina, South Carolina, and Tennessee. ${ }^{1}$ Since the 1987 amendments to the Federal Clean Water Act authorized

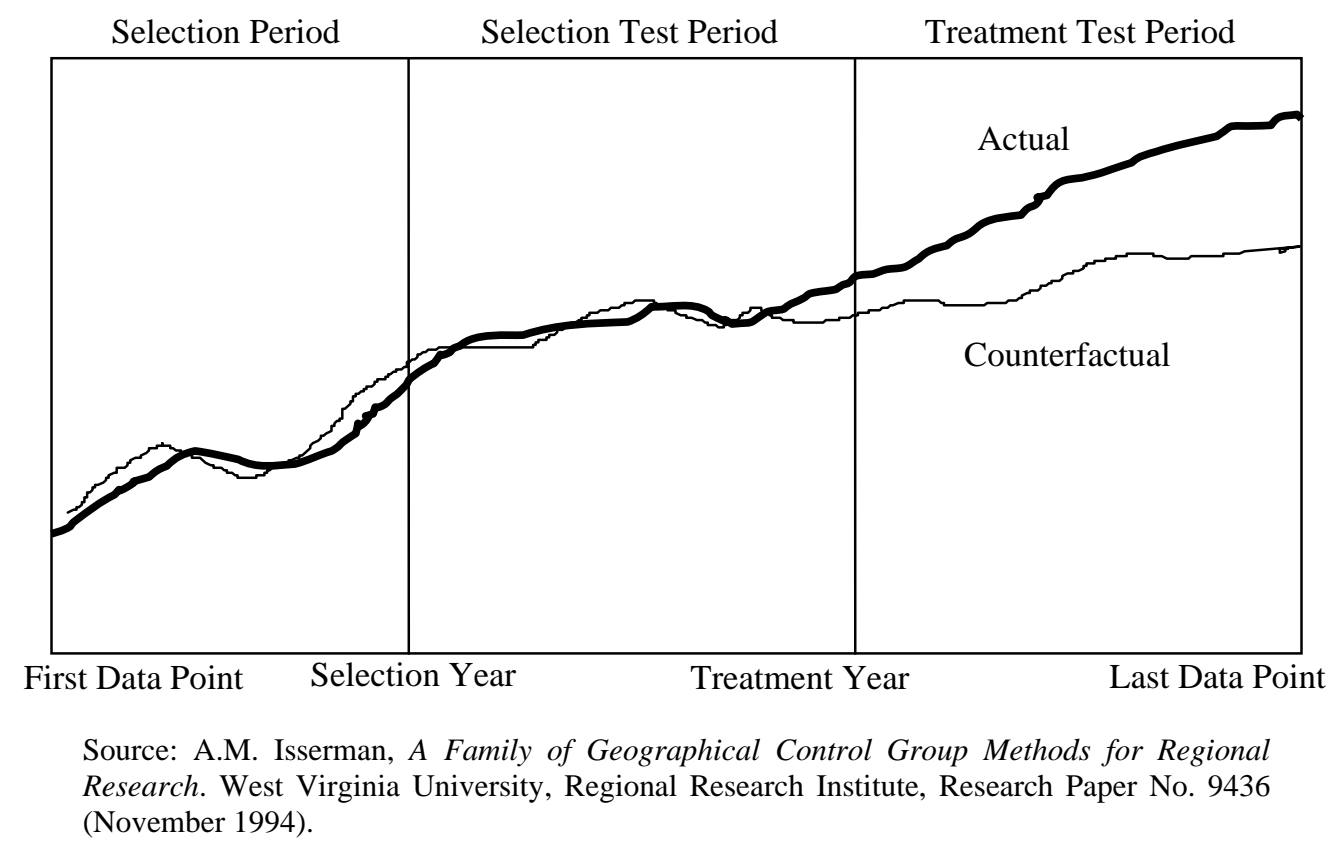

FIGURE 3. Hypothetical, Ideal Case of County Matching

\footnotetext{
${ }^{1}$ The Census Bureau's classification of "rural" consists of all territory, population, and housing units located outside of urbanized areas (UAs) and urban clusters (UCs). The rural component contains both place and non-place territory. It delineates UA and UC boundaries to encompass densely settled territory, which consists of: core census block groups or blocks that have a population density of at least 1,000 people per square mile and surrounding census blocks that have an overall density of at least 500 people per square mile.
} 
federal monies to establish revolving funds for low-interest loans to construct new and expand public wastewater facilities, six out of these eight southeastern states have established various forms of SRFs - Alabama in 1987, Georgia in 1986, Kentucky in 1988, North Carolina in 1989, South Carolina in 1989, and Tennessee in 1970. Therefore, the rural counties in these states that were identified as participating in SRF for funding water and wastewater projects were designated as treatment groups. Details about this group are discussed in the next section.

\subsection{Selecting Control Groups}

The states of Florida and Mississippi had no records of using SRF during the period of study, so they served for the control reservoir. Two steps were involved in the procedure of selecting control groups. The first was choosing the variables to define and identify similar places. Three types of variables are usually used - behavioral variable, policy variable, and the third type refers to properties of the data that would hinder the ability to conduct statistical tests, such as disclosure status and spatial proximity (Rephann 1993). Table 1 lists the different variables that were used to select control counties for this study.

The second step was choosing a selection method for sorting and matching a control region from the region reservoir for each treatment region. Some popular selection rules available are "sequential calipers matching," "nearest available matching," and "optimal matching” (Isserman and Merrifield 1982). This study uses optimal matching, which goes directly to the objective of minimizing the summed "Mahalanobis distances" over the group of pairs. ${ }^{2}$ This technique relies on an iterative optimization algorithm to obtain the best set of matches. Its most desirable feature is that it searches for the set of control matches, which minimizes the distance of the matches (taken as a group) from the treatment observations.

\subsection{Determining Control Group Size}

This study adopts a way to select the control group from a pool of control counties based on certain calipers. The basic caliper is to select the counties from the control pool that did not receive the treatment during the period under study. Next, as the research is concerned with the treatment of non-metro counties only, the second condition for elimination was to pick up only the non-metro counties in the study area. As a result, the four models in the pair-wise matching have four different control group sizes.

\footnotetext{
${ }^{2}$ The Mahalanobis distance, is defined as $\mathrm{d}\left(\mathrm{X}_{\mathrm{T}}, \mathrm{X}_{\mathrm{i}}\right)=\left(\mathrm{X}_{\mathrm{T}}-\mathrm{X}_{\mathrm{i}}\right)^{\prime} \Sigma^{-1}\left(\mathrm{X}_{\mathrm{T}}-\mathrm{X}_{\mathrm{i}}\right)$, where $\mathrm{d}\left(\mathrm{X}_{\mathrm{T}}, \mathrm{X}_{\mathrm{i}}\right)$ is the distance between the vector of selection variables for treated county and county $\mathrm{i}$, and $\Sigma$ is the variance-covariance matrix of the variables for the potential twins. The Mahalanobis metric implicitly scales and weighs the variables by a factor determined from the variability of data. If a variable has high variance, ceteris paribus, the variable will contribute less to the dissimilarity between the treatment region and a control candidate. The Mahalanobis metric is forgiving on those high-variance dimensions for which it is difficult to find close observations.
} 
TABLE 1

Description of Variables Used to Match Counties

\begin{tabular}{llc}
\hline Name & \multicolumn{1}{c}{ Variable Description } & Year \\
\hline \multicolumn{2}{l}{ Spatial Structure } & \\
TOTINC & Total income & 1979 \\
TOTPOP & Total population & 1979 \\
POPDENS & Population density & 1979 \\
PMSA & Proximity to metropolitan area & 1979 \\
Economic Structure & \\
PCI & Per capita income & 1979 \\
FARM & Farm earnings & 1979 \\
MANUF & Manufacturing earnings & 1979 \\
TRDNSRV & Combined earnings from the wholesale, retail, and service sectors \\
TRANSP & Transportation and public utilities earnings & 1979 \\
TRNSFRINC & Combined earnings from dividends, interest, \& rent (DIR) and & 1979 \\
& $\quad$ transfer payments sectors & 1979 \\
GOVTINC & Combined earnings from state \& local govt. federal civilian and & 1979 \\
& $\quad$ federal military sectors & 1979 \\
RESADJ & Residence adjustments (earnings from out commuters residing in the & \\
\multicolumn{2}{l}{ Previous Growth } & \\
INCGR & $\quad$ county less in commuter earnings) & $1970-79$ \\
POPGR & Total income growth rate & $1970-79$ \\
\hline
\end{tabular}

\section{DATA AND MODEL DESCRIPTION}

The classification of metro and non-metropolitan counties was made on the basis of the "rural/urban continuum codes" as defined by the Economic Research Service of the USDA (Butler and Beale 1994). This classification resulted in 380 rural counties in total from the states of Alabama, Georgia, Kentucky, North Carolina, South Carolina, and Tennessee. Out of these 380 counties, the survey reports revealed that only 36 non-metro counties participated in SRFs for infrastructure development during the period under study. Accordingly, these counties were grouped as the treated counties. Data disclosure problems finally settled the number of treated counties to 35. To set up the control reservoir, all the non-metropolitan counties from the states of Mississippi and Florida were chosen for the same period (1970-1995). There were 97 counties in total for this group.

As the survey reveals, among these eight states, Tennessee was the earliest to start with some kind of credit pooling system in the year 1970; North and South Carolina were the latest to start in 1989. To maintain consistency in the quasi-experimentation (Q-E) technique, 1989 was chosen as the treatment-starting year. This, however, opens up the possibility of overstating the growth patterns within the treatment group in the selection and selection test period, as some rural counties in the treatment group were already 
receiving treatment as early as 1970 . "Hierarchical cluster analysis" was used to minimize this bias. This method fuses the treatment region with other proximate regions into an initial cluster. At higher stages of the hierarchy, clusters are merged to form new clusters based on the distance between clusters (Aldenderfer and Blashfield 1984). Availability of data restricted the first data point and the last data point to the years 1970 and 1995, respectively (Figure 3). The selection of counties for the control group in the "selection period" is based on 1970-1979 growth rates and 1979 economic conditions. In the "selection test period" the growth rates of the control group were matched to the similar growth rates of the treated group for the next ten years - 1979 to 1988, just before the treatment begins. Thus the pre-test time frame traces out similarity in growth rates between the control group and the treated group. The treatment effect is studied in the "treatment test period" stretching to the next seven years from 1989 to 1995.

All four models had the same set of counties as the treatment group. The tables in the appendix list the treated counties and their matching counties from the control group for each model. The first model is an attempt to make an inter-state comparison with the 97 rural counties of Florida and Mississippi acting as the control reservoir for the 35 treated counties. The second model looks for an intra-state comparison with the 344 rural counties of the treated states (apart from the 35 treated counties) serving as the control reservoir. The third model attempts to synthesize the control reservoir of the previous two models to see whether there is any change in the results of the study. Here, 97 counties of the first model were added to the matrix of the 344 counties of the second model, which resulted in a huge matrix of 441 non-metropolitan counties. This control reservoir tries to take into account any regional differences that may have gone unaccounted for in the two previous models.

For all these three models, only the best possible match from the control reservoir, i.e., the county match that had a Mahalanobis ranking of one (because its Mahalanobis distance was minimum) was chosen as a twin for each treated county. However, the process of optimal matching by its nature picks up the second-ranked county as the best twin for a treated county if its first ranked county has already been matched to another treated county in the process. Consequently, in such situations a particular treated county tends to have a little less than "best" fitted match, although the process of optimal matching has a built-in mechanism of assigning matches so that the entire group of twins is as much like the entire group of treated counties as possible. In short, all three models suffer from imperfect matching problems that lead to biased estimates of the treatment (Reed and Rogers 2003). The bias is caused by (a) nonrandom sample of treatment counties and (b) avoiding duplication of control counties as twins. To reduce this bias, a suggested fourth model was set up.

In this Synthesized Composite County comparison model, the closeness or goodness of the matches were given more weight. Each treated county is assigned a twin that is a composite of the first five ranked rural counties (based on Mahalanobis distance), as opposed to a single twin that is just the first ranked (i.e., has the minimum Mahalanobis distance). Once again, the composites were chosen from the huge matrix of control 
groups used in the third model. Another improvement attempted in this model was to work without the "residence adjustment" variable as it had "disclosure" problems for many counties. The variable "population density" also seemed to be insignificant in the previous models and so was avoided in this model. For all four models, the time periods for the different test periods as hypothesized in Figure 3 remain the same.

\subsection{Source of Data}

Data on the variables listed in Table 1 were obtained from various secondary sources. The Previous Growth variables - total income growth rate (INCGR) and total population growth rate (POPGR) - were calculated based on the data collected from the U.S. Census Bureau publication, U.S.A. Counties CD-ROM 1994 and 1996. This was also the source of data for all the Economic Structure and Spatial Structure variables except for proximity to a metropolitan area (PMSA). Data for this variable were obtained from the City and County Data Book 1983, 1994. However, the Regional Economic Information System publications also had to be used to upgrade the data for the years 1994 and 1995.

The county matches are based on 1979 economic conditions and 1970-1979 growth rates, so similarity is measured several years even before the treatment began. The income data for the different sectors of the economy are usually reported in terms of millions of dollars. Since we are dealing with only certain key sectors of the economy, these income figures had to be converted into percentages of total income so that parity was maintained when calculating differences in growth rates for each pair of counties for the different variables.

Residential adjustment is treated differently than the other categories because it can assume negative values for counties that have a net outflow of commuters' income. This property creates a problem when doing the impact calculations because the growth rate of a negative number does not make intuitive sense.

Because of this problem, both the treatment effect on residential adjustment and the statistical significance tests of the effects were calculated using changes in residential adjustment's share of earned income (Rephann 1993). The procedure assumes that had there been no treatment, the treatment county's residential adjustment share would have changed by the median change for the control counties or by the same amount as the matched county.

\section{EMPIRICAL RESULTS}

If the control county is to be a good proxy for the growth of a treated county in the absence of loans from state credit pools after 1989, it should also closely track economic growth in the treated counties in the period between 1979 and 1988. Consequently, we tested the hypothesis that the mean difference of the rates of growth for all pairs of treated and control (composite) counties is zero prior to the treatment. Ideally, there should be no statistically significant difference between the growth rates of the treated 
counties and their twins in the pre-treatment period (pre-test). The univariate significance test was performed, which refers to statistically significant growth rate differences between the control group and the treatment region for an individual variable within the behavioral variable profile. The test is a $t$-test of the mean growth rate difference of the matched pairs. The growth rate difference is defined as

$$
D_{j t}^{T C}=r_{j t}^{T}-r_{j t}^{C},
$$

where $D$ is the growth rate difference, $T$ is the treated county $(T=1, \ldots, f), C$ is the untreated county $(C=1, \ldots, f), r_{j}$ is growth rate $j$ measured from base year $b, j$ is one of the economic variables used for performing the tests, and $t$ is the test year. The pair-wise matching method assumes that the mean of the pair-wise growth rate differences is distributed approximately normally.

A second type of significance test called global significance was performed that is an overall test of growth rate similarity for assessing the fitness of the twins during the pretest. The statistic used in testing here is the Hotelling $\mathrm{T}^{2}$ test statistic, a multivariate extension of the univariate $t$-test (Press 1972). For the post-treatment period, the univariate $t$-tests were run to test the hypothesis that the mean difference of the rates of growth for all pairs of treated and composite control counties was different from zero after the treatment.

\subsection{Model One - Inter-State Comparison}

The pre- and the post-test results of this model are reported in Table 2. As is noticeable, the treated counties had a per capita income higher than the control counties even before the treatment began. This reflects the endogeneity of the treated counties as discussed earlier - some of the treated counties had started enjoying credit pooling as early as 1970. Accordingly, the positive impact of this treatment might have already been felt by some of these counties. Total income and income in the farm sector for the treated counties appear to have been growing significantly faster than the untreated counties in the first half of the time period, but became insignificant between 1984 and 1988. However, the fact that a Hotelling $\mathrm{T}^{2}$ test (calculated to study the overall fitness of the twins) revealed no statistically significant differences suggests that the matches were good. ${ }^{3}$ Therefore, the pre-tests were passed and the twins were deemed adequate for use in the treatment period. The twins were matched on the basis of economic conditions only. Data availability restricted the use of other variables such as resource endowments and the political structure in the different states in the matching process.

For each treated county, its twin's growth rates established the counter-factual. If its twin grew 10 percent in population between 1988 and 1995, the treated county presumably also would have grown 10 percent. Thus, the key assumption is that the treated

3 The methodology to test global significance using Hotelling $\mathrm{T}^{2}$ was done following Timm (1975). 
TABLE 2

Pre- and Post-Test Results of Model One and Model Two by Category-Mean Growth Rate Differences

Between the Treated Counties and Their Twins

\begin{tabular}{|c|c|c|c|c|c|c|c|c|c|c|c|c|c|c|c|c|}
\hline & \multicolumn{8}{|c|}{ Model One } & \multicolumn{8}{|c|}{ Model Two } \\
\hline & \multicolumn{2}{|c|}{$\begin{array}{c}\text { Pre-Test } \\
\text { From } 1979 \text { to: }\end{array}$} & \multicolumn{6}{|c|}{$\begin{array}{c}\text { Post-Test } \\
\text { From } 1989 \text { to: }\end{array}$} & \multicolumn{2}{|c|}{\begin{tabular}{c|} 
Pre-Test \\
From 1979 to:
\end{tabular}} & \multicolumn{6}{|c|}{$\begin{array}{c}\text { Post-Test } \\
\text { From } 1989 \text { to: }\end{array}$} \\
\hline & 1984 & 1988 & 1990 & 1991 & 1992 & 1993 & 1994 & 1995 & 1984 & 1988 & 1990 & 1991 & 1992 & 1993 & 1994 & 1995 \\
\hline \multicolumn{17}{|l|}{ Variables } \\
\hline Total Income & $4.44^{*}$ & 1.71 & 1.37 & 2.65 & 1.02 & 1.85 & 1.33 & 1.39 & 0.87 & 0.68 & 0.29 & 0.91 & 0.65 & 1.84 & 1.87 & 1.83 \\
\hline Total Population & -0.09 & -0.04 & 0.33 & 0.60 & 1.84 & 1.71 & 1.26 & 1.05 & 1.28 & 1.48 & -0.04 & -0.46 & -0.18 & 0.31 & 0.67 & 0.67 \\
\hline Population Density & 0.30 & -0.05 & -1.18 & -0.79 & 0.40 & 1.11 & 0.78 & 0.29 & 1.71 & 1.43 & 1.25 & -0.48 & -0.17 & $7 \quad 0.34$ & 0.60 & 0.48 \\
\hline Per Capita Income & 5.33 & 2.91 & 0.70 & 1.67 & -0.98 & -0.89 & -1.00 & 0.99 & -2.40 & -1.11 & -0.13 & 0.69 & 0.13 & 2.18 & 2.08 & 1.79 \\
\hline Residence Adjustment & 0.27 & -0.13 & -0.01 & 1.02 & 1.94 & 0.89 & 1.04 & 0.61 & 1.03 & -1.04 & -0.49 & -0.69 & -0.91 & -0.85 & -0.85 & -0.93 \\
\hline \multicolumn{17}{|l|}{ Earnings by Sector } \\
\hline Farming & 2.21 & 1.63 & 2.22 & 2.59 & -1.10 & -0.35 & -1.05 & 0.50 & 0.62 & 1.06 & -0.12 & 0.68 & 0.71 & 1.09 & 0.49 & 1.50 \\
\hline Manufacturing & 0.01 & -0.09 & -0.05 & 0.05 & 0.98 & 0.91 & 1.05 & 1.56 & 0.75 & -0.05 & 0.12 & 0.35 & 1.75 & 1.70 & 1.55 & 1.72 \\
\hline Trdnsrv & 0.32 & 0.29 & 1.96 & 0.74 & -0.01 & -0.27 & -0.77 & 0.77 & -4.07 & -0.53 & 0.21 & 0.82 & -0.54 & 0.72 & 1.51 & 1.46 \\
\hline Transport & 0.47 & -0.24 & -2.27 & -2.36 & -1.13 & -0.72 & -1.06 & 1.16 & 0.59 & 1.19 & 0.49 & -1.38 & -1.17 & 0.61 & 0.52 & 0.01 \\
\hline Trnsfinc & -2.21 & -1.55 & 1.65 & 1.82 & 1.97 & 1.86 & 1.53 & 1.57 & -2.55 & -1.34 & 0.52 & -0.69 & -0.24 & 1.95 & 2.06 & 1.94 \\
\hline Govtinc & 1.25 & 0.82 & 3.44 & 4.88 & 4.35 & 3.45 & 2.78 & 2.43 & 0.65 & 0.46 & -0.13 & 0.09 & 0.54 & 0.93 & 0.97 & 1.05 \\
\hline \multicolumn{4}{|c|}{ Global Significance - Overall Fit of the Match: } & \multicolumn{2}{|c|}{ Model One } & \multicolumn{3}{|c|}{ Model Two } & & & & & & & & \\
\hline \multicolumn{4}{|l|}{ Hotelling $\mathrm{T}^{2}$} & \multicolumn{2}{|c|}{8.19} & \multicolumn{2}{|c|}{5.70} & & & & & & & & & \\
\hline F-Test Statistic & & & & \multicolumn{2}{|c|}{2.15} & \multicolumn{2}{|c|}{2.15} & & & & & & & & & \\
\hline
\end{tabular}


county would have grown in the same way that its twin did in the absence of the pooling system. The post-test mean growth rate differences ought to be a reflection of this assumption.

From the data it is evident that the treatment did not result in an increase in the per capita income in the treated counties in the post-treatment period. In fact, in the treated counties, growth in per capita income fell below that of the control counties from 1992 onwards. This is because the growth rate of population in the treated counties started to become higher in the post-treatment period than in the control counties, and it turns out to be proportionately higher than income growth for the same period. However, this positive impact on population growth cannot be credited solely to the treatment effect.

The only sector that showed a significant positive impact in the post-treatment period was the government sector, which involved earnings from state and local governments and incomes from the federal military and civilian sectors. A plausible reason could be that these treated counties had strong political choice for using SRFs that lead to government expansion. Evidently, most of the treated counties were using the funds for water, wastewater, and infrastructure development projects. These are small rural counties with very small tax-bases and/or low credit quality, which makes it even more justifiable in joining the credit pooling system to improve their credit rating (Ray, 1999).

\subsection{Model Two - Intra-State County Comparison}

In this model, each of the treated counties was matched to a control county from its respective state. Table 2 shows the results of the selection test period (pre-test) and the treatment test (post-test) period. Once again, the growth rate differences between the period 1979 to 1984 and 1988 were mostly insignificant, with the exception of the variables PCI, TRDNSRV, and TRNSFINC. However, the Hotelling $\mathrm{T}^{2}$ test statistic showed no statistical significance, implying once again the matches to be overall a good fit. Thus the next step to move on was to perform statistical tests to study the effects of the treatment in the post treatment periods.

One desirable result noticed in this model is that per capita income in the post-treatment period for the treated counties began to grow faster than the control counties. However, the growth rate difference became significantly higher only from 1993 onwards. So what made these treated twins have higher per capita income growth than those in model one? It could be that these counties were able to get more grants and aid from the federal government (because of strong lobbies) or had better structured banking systems that provided easy financing for community development. This hinted at a possible redistribution of income from the untreated counties to the treated counties within the same state as the control counties had to bear part of the costs of the projects. Again, this could be the result of the treated counties having a favorable credit quality (that enabled them to qualify for credit pooling easily) over the untreated counties. Necessary data on alternative financing availability for these states could not be obtained to perform further tests to study these effects. 
Another variable worth noticing was "Residence Adjustment." The growth rate of this variable for the treated counties started out to be higher than the control counties in the pretest period between 1979 and 1984, but thereafter became slower than the control counties. This indicated that less income leaked out of the treated counties as a result of nonresidents working there, and/or more income entered the counties as a result of county residents commuting elsewhere. However, none of these differences were statistically significant in any of the post-treated years.

\subsection{Model Three - Synthesized County Comparison}

This model attempted to improve the desirable treatment effects by merging the two control groups of the previous two models. The results of the selection test period and the treatment test period are reported in Table 3. As it turns out, there was not much improvement in the results. Per capita income still grew significantly slower in the treated counties than in the control counties in the first of the pre-treatment periods, but the difference became insignificant between 1984 and 1988. However, the overall fit of the match was good, as implied by the Hotelling $\mathrm{T}^{2}$ test statistic not being significant at the 5 percent level. The post-test results showed that the growth in the per capita income for the treated counties turned out to be significantly higher than their twins from 1993 onwards. This result was possible because (as the county matching in the appendix reveals) most of the control twins are in-state counties that led to the redistribution effect.

\subsection{Model Four - Synthesized Composite County Comparison}

As mentioned earlier, this model was somewhat different from the previous three models with respect to the structure of the control group. Here a composite of the first five ranked counties was chosen to be a match for a particular treated county. Each composite twin is an average of the growth rates of the five counties in the composite group. However, all of the matches were made on the basis of the 1979 economic conditions and 1970-1979 growth conditions, as in all the previous models. Table 3 shows the pre- and post-test results for this model.

Both the total personal income and per capita personal income variables in the pretest period showed a negative sign, implying that the treated counties were growing more slowly than the composite control counties with respect to these variables. But it was only the latter variable that was growing significantly slowly all through the pretest period. Among the earnings sector variables, once again it was the TRNSFINC combined earnings from DIR and transfer payments - that had a significant negative sign. However, as desired, the Hotelling $\mathrm{T}^{2}$ test statistic for the global significance turned out to be statistically insignificant, and so the matches are deemed a good fit.

One highly desirable effect of the treatment noticed in this model was that the growth rate of total income became significantly positive in all the post-treatment periods. However, the growth rate of per capita income remained negative in the post-treatment 
TABLE 3

Pre- and Post-Test Results of Model Three and Model Four by Category-Mean Growth Rate Differences

Between the Treated Counties and Their Twins

\begin{tabular}{|c|c|c|c|c|c|c|c|c|c|c|c|c|c|c|c|c|}
\hline & \multicolumn{8}{|c|}{ Model Three } & \multicolumn{8}{|c|}{ Model Four } \\
\hline & \multicolumn{2}{|c|}{$\begin{array}{c}\text { Pre-Test } \\
\text { From } 1979 \text { to: }\end{array}$} & \multicolumn{6}{|c|}{$\begin{array}{c}\text { Post-Test } \\
\text { From } 1989 \text { to: }\end{array}$} & \multicolumn{2}{|c|}{\begin{tabular}{|c|} 
Pre-Test \\
From 1979 to:
\end{tabular}} & \multicolumn{6}{|c|}{$\begin{array}{c}\text { Post-Test } \\
\text { From } 1989 \text { to: }\end{array}$} \\
\hline & 1984 & 1988 & 1990 & 1991 & 1992 & 1993 & 1994 & 1995 & 1984 & 1988 & 1990 & 1991 & 1992 & 1993 & 1994 & 1995 \\
\hline \multicolumn{17}{|l|}{ Variables } \\
\hline Total Income & 1.69 & -0.84 & 0.61 & $2.09^{*}$ & 1.46 & 1.84 & 1.88 & 1.63 & 1.95 & -1.02 & 1.84 & 2.79 & 2.32 & 2.22 & 2.11 & 1.91 \\
\hline Total Population & 0.32 & 0.34 & 0.23 & 0.31 & 0.46 & 0.56 & 0.79 & 0.52 & 0.38 & 0.40 & -0.19 & 0.10 & 0.45 & 0.78 & 1.00 & 0.65 \\
\hline Population Density & 0.65 & 0.52 & -0.26 & -0.19 & -0.23 & 0.07 & 0.34 & 0.18 & - & - & - & - & - & - & - & - \\
\hline Per Capita Income & -2.17 & -1.64 & 0.33 & 1.44 & 1.02 & 2.85 & 2.86 & 2.27 & -2.54 & -2.52 & 1.47 & 2.01 & -0.63 & 0.09 & -0.07 & -0.11 \\
\hline Residence Adjustment & 1.65 & 1.36 & -0.69 & -0.61 & -0.73 & -0.21 & -0.25 & -0.40 & - & - & - & - & - & - & - & - \\
\hline \multicolumn{17}{|l|}{ Earnings by Sector } \\
\hline Farming & 0.46 & 0.38 & 1.54 & 1.47 & 1.32 & 1.29 & 1.21 & 1.02 & 1.10 & 1.22 & 1.38 & 1.62 & 0.44 & 0.91 & 0.46 & 1.00 \\
\hline Manufacturing & 0.44 & -0.66 & -1.05 & -0.79 & -0.04 & 0.18 & 0.18 & 0.36 & -0.74 & -1.47 & -0.55 & 0.08 & 1.46 & 1.63 & 1.75 & 1.96 \\
\hline Trdnsrv & -2.01 & -1.28 & 1.33 & 1.29 & 1.29 & 1.81 & 1.98 & 2.29 & -2.73 & -0.45 & -0.01 & 0.33 & -1.28 & 0.56 & 0.60 & 1.32 \\
\hline Transport & 0.28 & 0.25 & 0.39 & -0.55 & -1.54 & 0.31 & 0.34 & 0.23 & 0.29 & 0.07 & 0.86 & -1.52 & -1.91 & -0.22 & -0.62 & -0.58 \\
\hline Trnsfinc & -2.51 & -1.21 & 0.13 & 0.05 & -0.54 & 1.26 & 1.51 & 1.33 & -3.57 & -2.57 & 1.45 & 0.63 & 0.67 & 2.14 & 2.40 & 2.00 \\
\hline Govtinc & 0.82 & -0.01 & 0.07 & 1.13 & 0.85 & 1.01 & 0.97 & 0.96 & 1.30 & 0.37 & 0.72 & 1.81 & 2.46 & 1.94 & 1.80 & 1.71 \\
\hline \multicolumn{4}{|c|}{ Global Significance - Overall Fit of the Match: } & \multicolumn{2}{|c|}{ Model Three } & \multicolumn{3}{|c|}{ Model Four } & & & & & & & & \\
\hline Hotelling $\mathrm{T}^{2}$ & & & & \multicolumn{2}{|c|}{1.71} & \multicolumn{2}{|c|}{2.25} & & & & & & & & & \\
\hline F-Test Statistic & & & & \multicolumn{2}{|c|}{2.15} & \multicolumn{2}{|c|}{2.37} & & & & & & & & & \\
\hline
\end{tabular}


period, implying that the treated counties on an average had lower per capita income than the control counties but was not significantly higher.

A plausible reason is that population for the same period in the treated counties was growing proportionately faster than income, which wiped out the effect in per capita income. Within the earnings sector, the desirable effect of having a significant positive growth was not noticed in any of the variables except TRNSFINC. Growth rate of income from the manufacturing sector changed signs from negative in the pre-test period to positive in the post-test period, but none of them was significant at the 5 percent level.

\section{SUMMARY AND CONCLUSION}

The usefulness of the Q-E method as a tool in the evaluation of credit pooling technique rests in careful selection of the control group. The better the fit in the pre-treatment period, the more likely the control counties will serve as a counterfactual. For that reason, various combinations of control groups were tried out in this research. The key evaluation question is: can any development that occurred in the treated counties in or after the year 1989 be attributed solely to the treatment effect - the credit pooling financing technique? The answer is certainly not straightforward! The problem with the "before and after" design is that during the period, processes other than the "treatment" might have caused new developments to occur throughout the study region. Data availability restricted the study of the simultaneous effects of these "other" possible treatments in this research.

Looking at how the Q-E method tries to explain the performance of the sector variables, we noticed that the impact of the treatment on the manufacturing sector showed to be positive in all the four models, although not significantly higher in any of the models. The least affected sector was the transport sector. That is because most of the infrastructure projects undertaken were for the improvement of water and/or wastewater treatment facilities, which does not have any direct impact on the transport sector unless, of course, a region is heavily dependent on water transportation. Surprisingly, the impact of the treatment was not significant on the farming sector in any of the models. Creating composite twins for each treated county in the fourth model had the significant result of creating a higher positive trend in total income and population for the treated counties. Thus, the Q-E tool shows some potential as an element to be considered for impact assessment in regional policy studies.

However, can these results be generalized to suggest that credit pooling is an efficient technique for financing infrastructure? Before an attempt is made to answer that, limitations of this study need to be discussed. First, because of the inadequate data availability on the borrowing structure of the counties, no financial variable could be incorporated and tested in the models. It would be interesting to find out how the institutional, structural, and political framework of these rural counties are conducive or detrimental in implementing the credit pooling system by adding some of these variables to the study. Second, no attempt was made to run any statistical control tests such as a multivariate 
regression analysis with some of the other financing instruments as independent variables. Regression analysis can be run as an alternative technique to study for major events occurring at the same time as the "treatment." With the above caveats in mind, the modest conclusion from this research is that we find some mixed evidence that credit pooling financing techniques do have some marginal positive impact on the economy, as measured by per capita income.

\section{REFERENCES}

Aldenderfer, M.S. and R.K. Blashfield, 1984. Cluster Analysis. Sage Publications.

Bender B. and S. Schwiff, 1982. "The Appropriation of Rents by Boomtown Governments,” Economic Inquiry 20, 84-103.

Blum, U., 1982. "Effects of Transportation Investments on Regional Growth; A Theoretical and Empirical Investigation,” Papers of the Regional Science Association 49, 169-184.

Briggs, R., 1980. The Impact of Interstate Highway System on Non-Metropolitan Growth. Washington D.C.: Office of University Research, U.S. Dept. of Transportation.

Butler, M.A. and C.L. Beale, 1994. "Rural-Urban Continuum Codes for Metro and Nonmetro Counties 1993,” USDA Staff Report No. 9425 (September), Agriculture \& Rural Economy Division, Economic Research Service.

Campbell, D.T. and J.C. Stanley, 1963. "Experimental and Quasi-Experimental Designs for Research on Teaching,” in N.L. Gage (ed), Handbook of Research on Teaching. Rand McNally \& Co.: Chicago.

Cook, T.D. and D.T. Campbell, 1979. Quasi-Experimentation-Design and Analysis Issues for Field Settings. Chicago: Rand McNally College Publication Co.

Farnsworth, D., 1972. The Ohio County Airport Study 1964-1972. Columbus, OH: Ohio Department of Commerce, Division of Aviation.

Fox, W.F., 1988. "Public Infrastructure and Economic Development,” in Rural Economic Development in the 1980s: Prospects for the Future" (September), U.S. Dept. of Agriculture, ERS, Agriculture and Rural Economy Division, Rural Development Research Report No. 69.

and T.R. Smith, 1990. "Public Infrastructure Policy and Economic Development," Economic Review.

Illyes, J., 1985. "State Bond Bank: More State Bond Banks Are Coming Soon," Institutional Research. John Nuveen \& Co. Inc.

Isard, W., 1960. Methods of Regional Analysis. Cambridge, MA: MIT Press.

Isserman, A.M., 1987. "Highways and Rural Economic Development: Results from Quasi-Experimental Approaches,” Research Paper 8907, Regional Research Institute, West Virginia University.

1994. "A Family of Geographical Control Group Methods for Regional Research,” Research Paper No. 9436 (November), West Virginia University, Regional Research Institute.

and J.D. Merrifield, 1982. "The Use of Control Groups in Evaluating Regional Economic Policy,” Regional Science and Urban Economics 12, 45-58. 
Johnson, T.G., 1996. "The Economic Impacts of Infrastructure Development," in T.D. Rowley, D.W. Sears, G.L. Nelson, J.N. Reid, and M.J. Yetley (eds), Rural Development Research: A Foundation for Policy. Westport, CT: Greenwood Press.

National League of Cities, 1987. "Financing Infrastructure - Innovations at the Local Level," Case Study Reports, December.

Petersen, J.E., S. Robinson, P. Aguila, J.L. Leuithe, and W. Graham, 1988. "Credit Pooling to Finance Infrastructure," Government Finance Officers Association Publication, Washington, D.C.

Press, S.J., 1972. Applied Multivariate Analysis. New York: Holt, Rinehart and Winston.

Ray, M., 1999. "Effectiveness of Credit Pooling Techniques for Infrastructure Development in Rural Communities: A Quasi-Experimental Analysis," Ph.D. Dissertation, Clemson University.

Reed, W.R. and C.L. Rogers, 2003. "A Study of Quasi-Experimental Control Group Methods for Estimating Policy Impacts,” Regional Science and Urban Economics 33(1), 3-25.

Rephann, T.J., 1993. “A Study of the Relationship Between Highway and Regional Economic Growth and Development Using Quasi-Experimental Control Group Methods,” Ph.D. Dissertation, West Virginia University.

Sears, D.W., T.D. Rowley, and N.J. Reid, 1990. "Infrastructure Investment and Economic Development: An Overview in Infrastructure Investment and Economic Development: Rural Strategies for the 1990s," Staff Report No. AGES 9069 (December), U.S. Dept. of Agriculture, Rural Economy Division.

Smith, B. and U. Harris \& Co., 1987. "Financing Clean Water: A Shift to State Initiative," Presented to the National Council of State Legislatures, Washington, D.C.

Timm, N.M., 1975. Multivariate Analysis with Applications in Education and Psychology. Brooks-Cole Publishers.

U.S. Department of Commerce, Bureau of Economic Analysis, 1994 \&1996. Regional Economic Information System CD-ROM. Washington D.C.: General Printing Office.

U.S. Department of Commerce, Bureau of the Census, 1983 \& 1994. "County and City Data Book.” Washington D.C.: General Printing Office.

U.S. Department of Agriculture, 1990. "Financial Market Intervention as a Rural Development Strategy,” ERS Staff Report No. AGES 9070, Agriculture and Rural Economy Division, Economic Research Service.

U.S. General Accounting Office, 2001. "U.S. Infrastructure: Funding Trends and Federal Agencies’ Investment Estimates” (July), Washington D.C.

Wheat, L., 1970. The Effect of Airline Service on Manufacturing Growth in Cities Below 40,000 Population. Washington D.C.: U.S. Dept. of Commerce, Economic Development Administration, 


\section{APPENDIX}

\section{TABLE A.1}

County Matches for Model One - Control Counties from Florida \& Mississippi States Only

\begin{tabular}{rlllll}
\hline \multicolumn{2}{c}{ Treated Counties } & Control Counties & \multicolumn{2}{c}{ Treated Counties } & Control Counties \\
\hline 1. & Barbour AL & Attala MS & 19. & Bell KY & Adams MS \\
2. & Bullock AL & Tunica MS & 20. & Boyle KY & Pike MS \\
3. & Cleburne AL & Choctaw MS & 21. & Breathitt KY & Wayne MS \\
4. & Covington AL & Monroe MS & 22. & Casey KY & Leake MS \\
5. & Cullman AL & Putnam FL & 23. & Clay KY & Franklin FL \\
6. & Marion AL & Scott MS & 24. & Fleming KY & Montgomery MS \\
7. & Randolph AL & Webster MS & 25. & Graves KY & Newton MS \\
8. & Wilcox AL & Noxubee MS & 26. & Grayson KY & Marion MS \\
9. & Winston AL & Chickasaw MS & 27. & Henry KY & George MS \\
10. & Bulloch GA & Yazoo MS & 28. & Letcher KY & Quitman MS \\
11. & Gordon GA & Union MS & 29. & Monroe KY & Tippah MS \\
12. & Jefferson GA & Calhoun FL & 30. & Simpson KY & Clay MS \\
13. & Lamar GA & Tate MS & 31. & Pender NC & Pearl River MS \\
14. & Murray GA & Pontotoc MS & 32. & Jasper SC & Benton MS \\
15. & Polk GA & Alcorn MS & 33. & Monroe TN & Marshal MS \\
16. & Pulaski GA & Simpson MS & 34. & Grundy TN & Prentiss MS \\
17. & Taylor GA & Gulf FL & 35. & Lawrence TN & Clarke MS \\
18. & Anderson KY & Gilcrist FL & & & \\
\hline
\end{tabular}


TABLE A.2

County Matches for Model Two - Control Counties from Within the Same States as the Treated Counties

\begin{tabular}{rlllll}
\hline \multicolumn{2}{r}{ Treated Counties } & Control Counties & \multicolumn{2}{c}{ Treated Counties } & Control Counties \\
\hline 1. & Barbour AL & Henry AL & 19. & Bell KY & Marion KY \\
2. & Bullock AL & Geneva AL & 20. & Boyle KY & Montegomery KY \\
3. & Cleburne AL & Bibb AL & 21. & Breathitt KY & Rockcastle KY \\
4. & Covington AL & Escambia AL & 22. & Casey KY & Todd KY \\
5. & Cullman AL & Tallapoosa AL & 23. & Clay KY & Leslie KY \\
6. & Marion AL & Pickens AL & 24. & Fleming KY & Edmonson KY \\
7. & Randolph AL & Lamar AL & 25. & Graves KY & Logan KY \\
8. & Wilcox AL & Choctaw AL & 26. & Grayson KY & Breckinridge KY \\
9. & Winston AL & Jackson AL & 27. & Henry KY & Garrard KY \\
10. & Bulloch GA & Sumter GA & 28. & Letcher KY & Lincoln KY \\
11. & Gordon GA & Jackson GA & 29. & Monroe KY & Wayne KY \\
12. & Jefferson GA & Meriwether GA & 30. & Simpson KY & Taylor KY \\
13. & Lamar GA & Lincoln GA & 31. & Pender NC & Bladen NC \\
14. & Murray GA & Gilmer GA & 32. & Jasper SC & Georgetown SC \\
15. & Polk GA & Chatooga GA & 33. & Grundy TN & Johnson TN \\
16. & Pulaski GA & Elbert GA & 34. & Lawrence TN & Hardeman TN \\
17. & Taylor GA & Stewart GA & 35. & Monroe TN & Cocke TN \\
18. & Anderson KY & Mercer KY & & & \\
\hline
\end{tabular}


TABLE A.3

County Matches for Model Three - Control Counties from All Eight Southeastern States

\begin{tabular}{|c|c|c|c|}
\hline Treated Counties & Control Counties & Treated Counties & Control Counties \\
\hline 1. $\quad$ Barbour AL & Colleton SC & 19. Bell KY & Marion KY \\
\hline 2. Bullock AL & Burke GA & 20. Boyle KY & Stephens GA \\
\hline 3. Cleburne AL & Bibb AL & 21. Breathitt KY & Wayne MS \\
\hline 4. Covington AL & Escambia AL & 22. Casey KY & Wayne KY \\
\hline 5. Cullman AL & Harnett NC & 23. Clay KY & Rockcastle KY \\
\hline 6. Marion AL & Tallapoosa AL & 24. Fleming KY & Metcalfe KY \\
\hline 7. Randolph AL & Jasper MS & 25. Graves KY & Lincoln TN \\
\hline 8. Wilcox AL & Amite MS & 26. Grayson KY & Overton TN \\
\hline 9. Winston AL & Lauderdale TN & 27. Henry KY & Garrard KY \\
\hline 10. Bulloch GA & Pike AL & 28. Letcher KY & Lincoln KY \\
\hline 11. Gordon GA & Warren TN & 29. Monroe KY & Ashe NC \\
\hline 12. Jefferson GA & Anson NC & 30. Simpson KY & Taylor KY \\
\hline 13. Lamar GA & Jackson GA & 31. Pender NC & Cheroke AL \\
\hline 14. Murray GA & Henderson TN & 32. Jasper SC & Crenshaw AL \\
\hline 15. Polk GA & Stanly NC & 33. Grundy TN & Morgan TN \\
\hline 16. Pulaski GA & Caldwell KY & 34. Lawrence TN & Henry TN \\
\hline 17. Taylor GA & Marion GA & 35. Monroe TN & Clarendon SC \\
\hline 18. Anderson KY & Mercer KY & & \\
\hline
\end{tabular}


TABLE A.4

County Matches for Model Four - Control Reservoir Same as Model Three

\begin{tabular}{|c|c|c|}
\hline $\begin{array}{l}\text { Treated } \\
\text { Counties }\end{array}$ & $\begin{array}{l}\text { Composite } \\
\text { Counties }\end{array}$ & Control Counties \\
\hline Barbour AL & 1 & Pike AL, Colleton SC, Pickens AL, Copiah MS, Attala MS \\
\hline Bullock AL & 2 & Burke GA, Warren GA, Dooly GA, Greene AL, Webster GA \\
\hline Cleburne AL & 3 & $\begin{array}{l}\text { Bibb AL, Hickman TN, Coosa AL, Meriwether GA, } \\
\text { Marion GA }\end{array}$ \\
\hline Covington AL & 4 & $\begin{array}{l}\text { Escambia AL, Monroe MS, Beaufort NC, Laurens GA, } \\
\text { Marengo AL }\end{array}$ \\
\hline Cullman AL & 5 & $\begin{array}{l}\text { Harnett NC, Greene TN, Wilkes NC, Rutherford NC, } \\
\text { Putnam FL }\end{array}$ \\
\hline Marion AL & 6 & $\begin{array}{l}\text { Lauderdale TN, Tallapoosa AL, Barnwell SC, Scott MS, } \\
\text { Montegomery NC }\end{array}$ \\
\hline Randolph AL & 7 & Jasper MS, Calhoun MS, Madison FL, Clay AL, Newton MS \\
\hline Wilcox AL & 8 & $\begin{array}{l}\text { Amite MS, Chickasaw MS, Sumter AL, Noxubee MS, } \\
\text { Chocktaw AL }\end{array}$ \\
\hline Winston AL & 9 & $\begin{array}{l}\text { Lauderdale TN, Barnwell SC, Montegomery NC, Banks GA, } \\
\text { Warren TN }\end{array}$ \\
\hline Bulloch GA & 10 & Pike AL, Sumter GA, Yazoo MS, Macon AL, Franklin TN \\
\hline Gordon GA & 11 & Warren TN, Hart GA, Person NC, Lauderdale TN, Macon TN \\
\hline Jefferson GA & 12 & $\begin{array}{l}\text { Anson NC, Meriwether GA, Greene GA, Pickens AL, } \\
\text { Warren NC }\end{array}$ \\
\hline Lamar GA & 13 & $\begin{array}{l}\text { Jackson GA, Hart GA, Yancey NC, Chatooga GA, Mercer } \\
\text { KY }\end{array}$ \\
\hline Murray GA & 14 & $\begin{array}{l}\text { Henderson TN, Pontotoc MS, Lewis TN, Gilmer GA, } \\
\text { Jeffdavis GA }\end{array}$ \\
\hline Polk GA & 15 & $\begin{array}{l}\text { Stanly NC, Chatooga GA, Jefferson TN, Jackson GA, Person } \\
\text { NC }\end{array}$ \\
\hline Pulaski GA & 16 & $\begin{array}{l}\text { Caldwell KY, Morgan GA, Dooly GA, Nicholas KY, } \\
\text { Bleckley GA }\end{array}$ \\
\hline Taylor GA & 17 & Marion GA, Warren NC, Saluda SC, Talbot GA, Jones NC \\
\hline Anderson KY & 18 & Mercer KY, Garrad KY, Pike GA, Trimble KY, Houston TN \\
\hline Bell KY & 19 & $\begin{array}{l}\text { Marion KY, Mitchell NC, Rockcastle KY, Toombs GA, } \\
\text { Pike MS }\end{array}$ \\
\hline Boyle KY & 20 & Stephens GA, Lee NC, Clarke AL, Tift GA, Pasquotank NC \\
\hline Breathitt KY & 21 & $\begin{array}{l}\text { Wayne MS, Rockcastle KY, Fentress TN, Jeffdavis MS, } \\
\text { Franklin FL }\end{array}$ \\
\hline Casey KY & 22 & $\begin{array}{l}\text { Wayne KY, Leake MS, Cumberland KY,Clinton KY, } \\
\text { Ashe NC }\end{array}$ \\
\hline Clay KY & 23 & $\begin{array}{l}\text { Rockcastle KY, Wayne MS, Cumberland TN, Fentress TN, } \\
\text { Wayne KY }\end{array}$ \\
\hline Fleming KY & 24 & $\begin{array}{l}\text { Metcalfe KY, Montegomery MS, Edmonson KY, } \\
\text { Marion KY, Jeffdavis MS }\end{array}$ \\
\hline Graves KY & 25 & Lincoln TN, Giles TN, Weakley TN, Dyer TN, Beaufort NC \\
\hline
\end{tabular}




\begin{tabular}{|c|c|c|}
\hline $\begin{array}{c}\text { Treated } \\
\text { Counties }\end{array}$ & $\begin{array}{c}\text { Composite } \\
\text { Counties }\end{array}$ & Control Counties \\
\hline Grayson KY & 26 & $\begin{array}{l}\text { Overton TN, Prentiss MS, Tippah MS, Mcnairy TN, } \\
\text { Wayne KY }\end{array}$ \\
\hline Henry KY & 27 & $\begin{array}{l}\text { Garrard KY, Trimble KY, Bracken KY, Saluda SC, } \\
\text { Bleckley GA }\end{array}$ \\
\hline Letcher KY & 28 & $\begin{array}{l}\text { Lincoln KY, Rockcastle KY, Franklin GA, Knox KY, } \\
\text { Benton TN }\end{array}$ \\
\hline Monroe KY & 29 & Wayne KY, Ashe NC, Truetlen GA, Clinton KY, Overton TN \\
\hline Simpson KY & 30 & $\begin{array}{l}\text { Taylor KY, White TN, Evans GA, Jeffdavis GA, } \\
\text { Aleghany NC }\end{array}$ \\
\hline Pender NC & 31 & $\begin{array}{l}\text { Cheroke AL, Chilton AL, Worth GA, George MS, } \\
\text { Pearlriver MS }\end{array}$ \\
\hline Jasper SC & 32 & $\begin{array}{l}\text { Crenshaw AL, Macintosh GA, Macon NC, Fannin GA, } \\
\text { Breckinridge KY }\end{array}$ \\
\hline Grundy TN & 33 & $\begin{array}{l}\text { Morgan TN, Yancey NC, Bledsoe TN, Lewis KY, } \\
\text { Jackson TN }\end{array}$ \\
\hline Lawrence TN & 34 & $\begin{array}{l}\text { Henry TN, Lamar AL, Hardeman TN, Hardin TN, } \\
\text { Mcnairy TN }\end{array}$ \\
\hline Monroe TN & 35 & $\begin{array}{l}\text { Clarendon SC, Morgan TN, Marshall MS, Cocke TN, } \\
\text { Pickens AL }\end{array}$ \\
\hline
\end{tabular}

